\title{
COMPARISON BETWEEN CLIMATOLOGICAL AND FIELD WATER BALANCES FOR A COFFEE CROP
}

\author{
Isabeli Pereira Bruno ${ }^{1}$; Adriana Lúcia da Silva²; Klaus Reichardt ${ }^{3 *}$; Durval Dourado-Neto ${ }^{4}$; \\ Osny Oliveira Santos Bacchi³ Clóvis Alberto Volpe ${ }^{5}$ \\ ${ }^{1}$ USP/ESALQ - Programa de Pós-Graduação em Fitotecnia, C.P. 9 - 13418-900 - Piracicaba, SP - Brasil. \\ ${ }^{2}$ UNICAMP/COTIL - Depto. de Geomática, Av. Cônego Manoel Alves, 129 - 13484-420 - Limeira, SP - Brasil. \\ ${ }^{3}$ USP/CENA - Lab. de Física do Solo, C. P. 96, 13416-903 - Piracicaba, SP - Brasil. \\ ${ }^{4}$ USP/ESALQ - Depto. de Produção Vegetal, C.P. 9 - 13418-900 - Piracicaba, SP - Brasil. \\ ${ }^{5}$ UNESP/FCAV - Depto de Ciências Exatas, Via de Acesso Prof.Paulo Donato Castellane, s/n, 14884-900 - \\ Jaboticabal, SP - Brasil. \\ *Corresponding author<klaus@cena.usp.br>
}

\begin{abstract}
The use of climatological water balances in substitution to complete water balances directly measured in the field allows a more practical crop management, since the climatological water balances are based on data monitored as a routine. This study makes a comparison between these methods in terms of estimatives of evapotranspiration, soil water storage, soil available water, runoff losses, and drainage below root zone, during a two year period, taking as an example a coffee crop of the variety Catuaí, three to five years old. Climatological water balances based on the estimation of the evapotranspiration through the methods of Thornthwaite and Penman-Monteith, can reasonably substitute field measured balances, however underestimating the above mentioned variables.

Key words: evapotranspiration, soil water storage, available water, water deficit, water excess

\section{COMPARAÇÃO ENTRE BALANÇOS HÍDRICOS CLIMATOLÓGICOS E DE CAMPO PARA UMA CULTURA DE CAFÉ}

\begin{abstract}
RESUMO: A utilização de balanços hídricos climatológicos em substituição aos balanços hídricos completos e medidos diretamente no campo permite um manejo da cultura de forma mais prática, pois os balanços hídricos climatológicos se baseiam em dados coletados rotineiramente. Foi feita comparação entre estes balanços em termos de estimativas de evapotranspiração, armazenamento de água no solo, capacidade de água disponível, perdas por escoamento superficial e drenagem profunda, por um período de dois anos, tomando como exemplo a cultura de café, variedade Catuaí, de três a cinco anos de idade. Os balanços hídricos climatológicos baseados na estimativa da evapotranspiração pelos métodos de Thornthwaite e Penman-Monteith substituem razoavelmente as medidas de campo, porém subestimando as variáveis mencionadas.

Palavras-chave: evapotranspiração, armazenamento de água no solo, água disponível, défice hídrico, excesso hídrico
\end{abstract}

\section{INTRODUCTION}

Water balances are the contabilization of water fluxes or quantities that enter or leave a chosen volume element of a cropped soil, during a period of time, resulting the net flux or quantity that remains available for plants, in this way estimating water deficits or excesses (Sentelhas \& Angelocci, 2005). This contabilization can be made through direct measurements of all components in the field (Reichardt \& Timm, 2004), or estimated from climatological data through the use of specific programs (Pereira et al., 2002).
In order to standardize the evapotranspiration of a reference surface, the concept of reference evapotranspiration (ETo) was introduced, which corresponds to the loss of a hypotetical grass crop of low height $(0.12 \mathrm{~m})$, with a air-flow resistance of $70 \mathrm{~s} \mathrm{~m}^{-1}$ and an albedo of 0.23 (Allen et al., 1998). Based on climatological data, the method of Thornthwaite (1948) was developed to estimate ETo, also called potential evapotranspiration, using air temperature as the main parameter. Today the most indicated method to estimate ETo is that of Penman-Monteith, parameterized by FAO, and that of the Class A pan, due to its simplicity (Allen et al., 1998). A crop coefficient (Kc) is used to trans- 
form the grass ETo into the crop potential evapotranspiration (ETc), which is a function of the phenological phases of the crop, crop species and variety, plant architecture and leaf area. Pereira (1986) used with success the climatologic water balance to study maximum and minimum soil water storages for a podzolic soil of the São Paulo State, in Brazil. Souza et al. (2002) made an analysis of the climatologic water balance simulation for the coffee crop, irrigated under different management conditions in Lavras, MG, Brazil. They employed an economic risk analysis model applied to irrigation project planning, called MORETTI, and its objectives consisted in evaluating the best choices of the model to estimate evapotranspiration and soil water storage. Meireles et al. (2003) characterized water excess and deficiency periods using a serial or sequential water balance, applied to a coffee crop of Mococa, SP, Brazil, one of the main Coffeea arabica producing regions. Brunini et al. (2003) adapted and converted the Thornthwaite \& Mather method to monitor the agrometeorological conditions of the coffee crop, including diverse soil and climate conditions.

Since the direct establishment of water balances is time consuming, experimentally difficult and costly, and climatologic simulations are simple and allow extrapolations to other situations (Faria \& Chibana, 2003; Souza et al., 2002), this study is a comparison between a well measured and complete coffee field water balance, and sequential climatologic water balances.

\section{MATERIAL AND METHODS}

\section{Field Water Balance}

This type of water balance, here called Bal C, uses the classical mass conservation law (Reichardt \& Timm, 2004) in which the water flux densities $\left(\mathrm{mm}\right.$ day $\left.^{-1}\right)$ entering and leaving a control volume determine its changes in soil water storage, when integrated over a time period $\left(\mathrm{t}_{\mathrm{i}+14}-\mathrm{t}_{\mathrm{i}}\right)=\Delta \mathrm{t}=14$ days:

$\int_{t_{i}}^{t_{+1+4}} p d t+\int_{t_{i}}^{t_{t+14}} d d t-\int_{t_{i}}^{t_{i+14}} e d t-\int_{t_{i}}^{t_{t+14}} r d t \pm \int_{t_{i}}^{t_{+1+4}} q_{L} d t+\int_{t_{i}}^{t_{+1+1}} \int_{0}^{L} \frac{\partial \theta}{\partial t} d z d t=0(1)$

where " $p$ " is the rainfall intensity, " $i$ " the irrigation rate, "e" the evapotranspiration rate, " $r$ " the runoff rate, " $\mathrm{q}_{\mathrm{L}}$ " the soil water fluxes at the lower boundary $(\mathrm{z}=\mathrm{L})$, " $\theta$ " the volumetric soil water content $\left(\mathrm{m}^{3} \mathrm{~m}^{-3}\right)$, and " $\mathrm{z}$ " the vertical position coordinate. Solving the integrals of eq (1) in relation to time, we obtain:

$\mathrm{P}+\mathrm{I}-\mathrm{ER}-\mathrm{RO} \pm \mathrm{QL} \pm\left(\mathrm{S}_{\mathrm{i}+14}-\mathrm{S}_{\mathrm{i}}\right)=0$

where all the units of the integrated components are given in $\mathrm{mm}$ : $\mathrm{P}$ the rainfall; I the irrigation; ER the actual evapotranspiration; $R O$ the runoff; $Q_{L}$ the drain- age or upward flow contribution at the lower boundary of the control volume; $\mathrm{S}$ the soil water storage of the $0-\mathrm{L}$ soil layer al $\mathrm{t}_{\mathrm{i}}$ and $\mathrm{t}_{\mathrm{i}+14}$ :

$\mathrm{S}_{\mathrm{i}+14}-\mathrm{S}_{\mathrm{i}}=\Delta \mathrm{S}=\int_{t_{i}}^{t_{i+14}} \int_{0}^{L} \frac{\partial \theta}{\partial t} d z d t$

Equation (2) was applied to data of five replicates of direct field measurements of all components, leaving the actual evapotranspiration ER as an unknown (Silva et al., 2006). Reference evapotranspiration ETo was estimated through the Penman-Monteith method FAO - 1998 cited by Pereira et al. (2002) and the maximum evapotranspiration of the crop was obtained through the use of a crop coefficient estimated in the same experiment. Rainfall and irrigation were measured with "Ville de Paris" raingages; soil water storage was calculated through the trapezoidal method, for the $1 \mathrm{~m}$ soil layer $(\mathrm{L}=1 \mathrm{~m})$, using neutron probe soil moisture valuations; runoff was measured on $12 \mathrm{~m}^{2}$ framed sub-plots, colleting the surface water flow by gravity in $200 \mathrm{~L}$ tanks located down slope; and the soil water fluxes at the lower boundary were calculated through the Darcy-Buckingham approach using a $K(\theta)$ relation obtained in the same field (Silva et al., 2007) and hydraulic gradients measured through tensiometers installed in the soil profile.

\section{Crop Climatological Water Balances}

These were obtained using computational programs (Rolim \& Sentelhas, 2006), which are based on the methods of Thornthwaite \& Mather (1955) and Penman-Montheith (Allen et al., 1998) that estimate soil water storages using mainly climate and soil physical characteristics information. The one based on Thornthwaite is here called Bal T and the other, based on Penman-Monteith, Bal PM.

These balances follow a simplified balance equation:

$\pm \triangle \mathrm{ARM}=P-E T c-D P$

where $\triangle A R M$ is the change in soil water storage $(\mathrm{mm})$ and refers to a $1 \mathrm{~m}$ soil layer. The sign of $\triangle \mathrm{ARM}$ indicates water deficit when negative and water excess when positive. When $\triangle \mathrm{ARM}$ is negative, the deep drainage (DP) is zero, and when positive it includes runoff and DP. $\mathrm{P}$ is the rainfall $(\mathrm{mm})+$ irrigation $(\mathrm{mm})$; ETc is the maximum (or potential) crop evapotranspiration (mm); DP is the drainage below root zone $(\mathrm{mm})$. The program that also allows the estimation of soil water extraction and reposition, requires input data for Bal $\mathrm{T}$ as follows: $1^{\text {st }}$ ) available soil water capacity (ASWC):

$\mathrm{ASWC}=\mathrm{S}_{\mathrm{FC}}-\mathrm{S}_{\mathrm{PWP}}$ 
where " $\mathrm{S}_{\mathrm{FC}}$ " is the soil water storage at field capacity and " $\mathrm{S}_{\mathrm{PWP}}$ " at permanent wilting point, both in $\mathrm{mm}$ for the $1 \mathrm{~m}$ soil layer; $2^{\text {nd }}$ ) The soil water storage prior to the start of the calculations, given by the difference between " $\mathrm{S}_{\mathrm{i}}$ " of eq (3) for $\mathrm{i}=1$, and " $\mathrm{S}_{\text {PWP }}$ "; $3^{\text {rd }}$ ) the local latitude; $4^{\text {th }}$ ) the year; $5^{\text {th }}$ " $N D Y$ " that corresponds to the number of the day of the year at which the balance begins; $6^{\text {th }}$ ) the heat index "I" and "a", from the cubic function of "I" of Thornthwaite \& Mather; $7^{\text {th }}$ ) the number of days that the balance covers, i. e., " $\Delta \mathrm{t}$ " of eq (1) and (2); $\left.8^{\text {th }}\right)$ average air temperature $\left({ }^{\circ} \mathrm{C}\right)$ for each period; $9^{\text {th }}$ ) rainfall plus irrigation for each period; and $10^{\text {th }}$ ) the crop coefficient $(\mathrm{Kc})$.

For Bal PM, items 6 and 8 are replaced by "ETc" calculated through the Penman-Monteith method. For Bal T, the outputs are: $\left.1^{\text {st }}\right) \mathrm{N}$ is the number of sunshine hours; $2^{\text {nd }}$ ) ETP the Thornthwait's potential evapotranspiration; $3^{\text {rd }}$ ) ETc the crop potential evapotranspiration $\left.(\mathrm{ETc}=\mathrm{Kc} . \mathrm{ETP}) ; 4^{\text {th }}\right)(\mathrm{P}-\mathrm{ETc})$ the water deficit of the period; $5^{\text {th }}$ ) (NEG AC) the sum of the sequence of negative values of $\left.(\mathrm{P}-\mathrm{ETc}) ; 6^{\text {th }}\right)$ "ARM" the soil water storage at the end of each period; $\left.7^{\text {th }}\right) \triangle$ ARM or ALT the soil water storage change for each period; $8^{\text {th }}$ ) ETR the actual crop evapotranspiration; $\left.9^{\text {th }}\right)$ DEF the water deficit for the crop, during the period; $10^{\text {th }}$ ) EXC the water excess in the period. For Bal PM output 1 does not exist, output 2 is the Penman- Montheith ETP input, and all the other are the same.

\section{Balance comparison}

To compare the balances, they were applied for the same crop at the same location. Data for the $50 \mathrm{Bal}$ $\mathrm{C}$ of 14 days each, were collected and analyzed by Silva (2005), and also used to estimate Bal T and Bal $\mathrm{PM}$, using temperature, relative humidity and wind speed recorded by an automatic weather-station located $200 \mathrm{~m}$ from the experimental site (Climapiracicaba, 2006).

Water balances were calculated for a coffee crop (Coffea arabica L.), variety Catuaí, line IAC-144, starting at its second year of age, grown in Piracicaba, SP, Brazil (22 $2^{\circ} 42^{\prime} \mathrm{S} ; 4^{\circ} 38^{\prime} \mathrm{W}, 580 \mathrm{~m}$ above sea level) on a Rhodic Kandiudalf, locally called "Nitossolo Vermelho Eutroférrico" (Embrapa, 1999). They started on September 01, 2003 and continued in periods of 14 days, during two years. At the beginning plants were $1.2 \mathrm{~m}$ tall, having $100 \%$ of their root system within the control volume of $1.0 \mathrm{~m}$ depth. At the end plants reached $2.0 \mathrm{~m}$ and more than $98 \%$ of the root system was still within this volume. The climate at Piracicaba is of the "Cwa" type according to Köppen, called "tropical highland", mesothermic with dry winter, average temperature of the coldest month below $18^{\circ} \mathrm{C}$ and that of the warmest month below $22^{\circ} \mathrm{C}$. Long term yearly averages are: rainfall $1,247 \mathrm{~mm}$; air temperature $21.1^{\circ} \mathrm{C}$; relative humidity $74 \%$. The dry season occurs between April and September, July being the driest month, its rainfall not exceeding $30 \mathrm{~mm}$ (Villa Nova, 1989).

To compare Bal C with Bal T and Bal PM, obtained through equations (2) and (4), respectively, it is important to remind: $\left.1^{\text {st }}\right) \mathrm{P}$ of $\mathrm{Bal} \mathrm{T}$ and $\mathrm{Bal} \mathrm{PM}$ include $(\mathrm{P}+\mathrm{I})$ of $\left.\mathrm{Bal} \mathrm{C} ; 2^{\text {nd }}\right)$ ETR and ER are equivalent but obtained through different methods; $\left.3^{\text {rd }}\right) \mathrm{ARM}=$ $\left.\left.\mathrm{S}_{\mathrm{i}}-\mathrm{S}_{\mathrm{PMP}} ; 4^{\text {th }}\right) \Delta \mathrm{ARM}=\mathrm{ALT}=\mathrm{DS} ; 5^{\text {th }}\right) \mathrm{EXC}=\mathrm{RO}+$ $\mathrm{QL}$. The comparison between evaluated components was made through linear regressions of their values obtained in sequence for 50 balances. For Bal $\mathrm{T}$ and $\mathrm{Bal}$ PM, the following soil data were used, which correspond to those of Bal C: $1^{\text {st }}$ ) ASWC $=150 \mathrm{~mm}$, with $\mathrm{S}_{\mathrm{cc}}=370 \mathrm{~mm}$ and $\mathrm{S}_{\mathrm{PMP}}=220 \mathrm{~mm} ; 2^{\text {nd }}$ ) Previous soil water storage $=25.2 \mathrm{~mm} ; 3^{\text {rd }}$ ) latitude $\phi=-22.72^{\circ} ; 4^{\text {th }}$ ) year $\left.2003 ; 5^{\text {th }}\right) \mathrm{NDY}=243$, corresponding to September $\left.1 ; 6^{\text {th }}\right) \mathrm{I}=108.4$ and $\left.\mathrm{a}=2.4 ; 7^{\text {th }}\right) \Delta \mathrm{t}=14$ days; $8^{\text {th }}$ ) $\mathrm{Kc}=1.0$, obtained by Silva (2005).

\section{RESULTS AND DISCUSSION}

Due to methodological differences, mainly with respect to the evaluation of the actual evapotranspiration (ER and ETR) and to the way by which water extraction is calculated, the results are expected not to be similar. For Bal T and Bal PM the soil water storage as a function of time $t$, for a given available water capacity, is exponentially related to the negative difference ETP - P, while for Bal C it is directly measured in the field. Even though the comparison was made, in order to satisfy the objective of this study since it would be very advantageous to replace the more difficult field evapotranspiration measurement by the straight forward climatological methods. Figure 1 shows the 50 fourteen day balances evolution of the coffee actual evapotranspiration evaluated through the

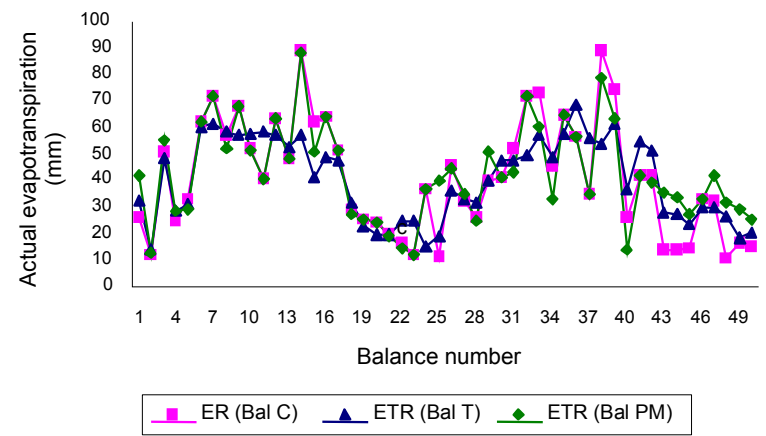

Figure 1 - Evolution of the actual evapotranspiration of the coffee crop for the 50 balances, through the field method (ER, $\mathrm{Bal}$ C) and the climatologic methods (ETR, Bal T and Bal PM). 
three methods. There is a good agreement between methods, with a tendency of Bal T and Bal PM to underestimate $\mathrm{Bal} \mathrm{C}$, as expected. The linear regressions between them (Figure 2), both with significant $\mathrm{R}^{2}$ values at the level of $1 \%$ through the $\mathrm{F}$ test, evidence the superiority of $\mathrm{Bal} \mathrm{PM}$ in relation to $\mathrm{Bal} \mathrm{T}$ in the estimation of the evapotranspiration evaluated by $\mathrm{Bal} \mathrm{C}$. The regression equations have slopes less than 1.0 and positive intercepts, indicating values of ER always higher than ETR. At the end of the first year (balance 25 ) the balances sheets show that the accumulated evapotranspirations of the three methods were $1,269 \mathrm{~mm}$ (Bal C); 1,083 mm (Bal PM); and 1,009 mm (Bal T), with differences of the last two in relation to $\mathrm{Bal} \mathrm{C}$ of 186 and $260 \mathrm{~mm}$, respectively, showing that the field measured evapotranspiration ER was underestimated by 14.7 and $20.5 \%$ by Bal PM and Bal T, respectively. For the second year (balances 26 to 50 ), these numbers were 1,$162 ; 1,060$; and $1,052 \mathrm{~mm}$, with differences of 8.8 and $9.5 \%$, respectively. Over the two year period the differences were 12 and $15 \%$, respectively.

In relation to the changes of soil water storage at the end of each 14 days period, $\mathrm{S}_{\mathrm{i}+14}-\mathrm{S}_{\mathrm{i}}$ for $\mathrm{Bal}$ $\mathrm{C}$ and $\triangle \mathrm{ARM}$ (or ALT) for Bal T and Bal PM, differences between methods were also observed (Figure 3) but, in a general way, they follow each other, with a superiority of Bal PM in relation to Bal T. These differences are explained by the fact that $\triangle \mathrm{ARM}$ is the result of several operations carried out by the computacional program, which include the evapotranspiration, and that each balance " $\mathrm{i}$ " depends on the previous one, in a sequential form. Due to this, the linear regressions between their values (Figure 4) had relatively low values of $\mathrm{R}^{2}$, however significant at $1 \%$ by the $\mathrm{F}$ test. The equation, with slopes less than 1.0 and intercepts close to zero, also shows a larger variability of $\Delta \mathrm{S}$ as compared to $\Delta \mathrm{ARM}$. With larger evapotranspiration values estimated by $\mathrm{Bal} C$, the larger values of $\Delta \mathrm{S}$ in relation to $\triangle \mathrm{ARM}$ are a simple consequence.

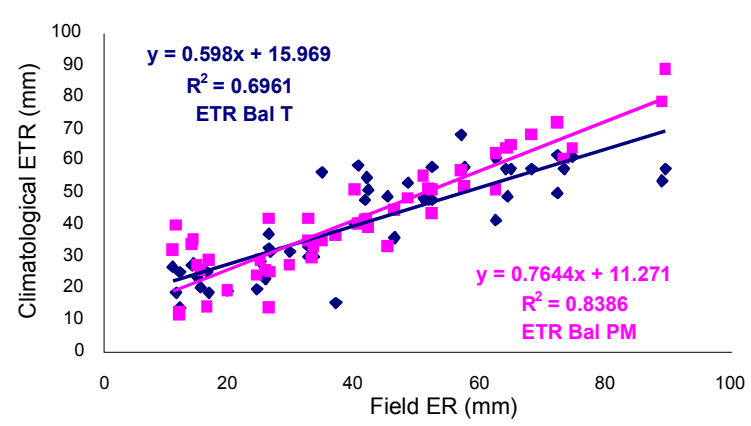

Figure 2 - Linear regressions between ETR (mm) of the climatologic balances (Bal T and Bal PM) and ER $(\mathrm{mm})$ of the field balance.
The amount of available soil water ASW at the end of each balance (Figure 5) shows a relative discrepancy among the methods, and their comparison through linear regressions (Figure 6) also presented significant $R^{2}$ values, however relatively low. The slopes of the regressions are close to 1.0, indicating that the changes of both are similar. They however, have different intercepts, 18.7 for Bal PM and 36.7 for $\mathrm{Bal} \mathrm{T}$, which result in higher values of $\mathrm{Bal} \mathrm{T}$ and $\mathrm{Bal}$ $\mathrm{PM}$ in relation to $\mathrm{Bal} \mathrm{C}$. Up to balance 11 there was a very good agreement between $\mathrm{Bal} T$ and $\mathrm{Bal} \mathrm{C}$, with a slight under-estimation of Bal PM.

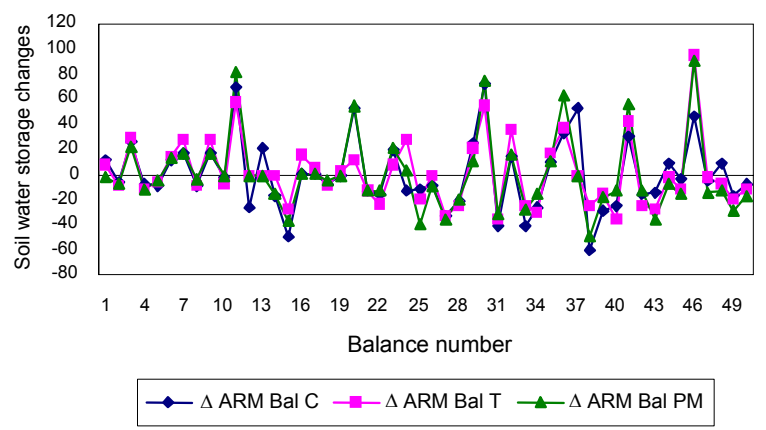

Figure 3 - Soil water storage changes in $\mathrm{mm}$ for the 50 balances, calculated by the three methods.

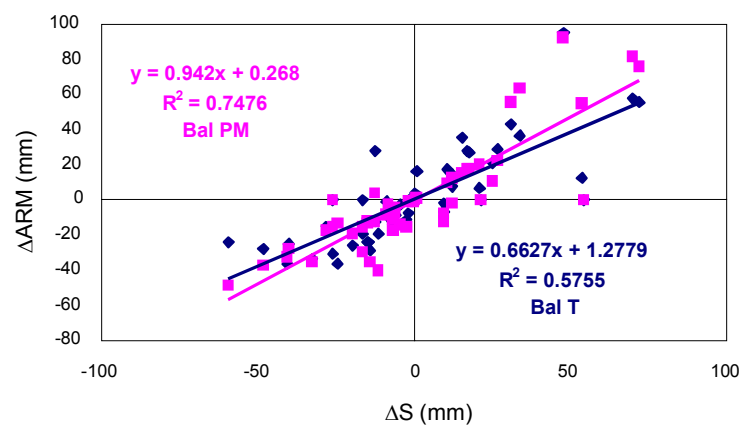

Figure 4 - Linear regressions between soil water storage changes $\triangle \mathrm{ARM}(\mathrm{mm})$ for $\mathrm{Bal} \mathrm{T}$ and $\mathrm{Bal} \mathrm{PM}$ in relation to $\Delta \mathrm{S}$ $(\mathrm{mm})$ of Bal C.

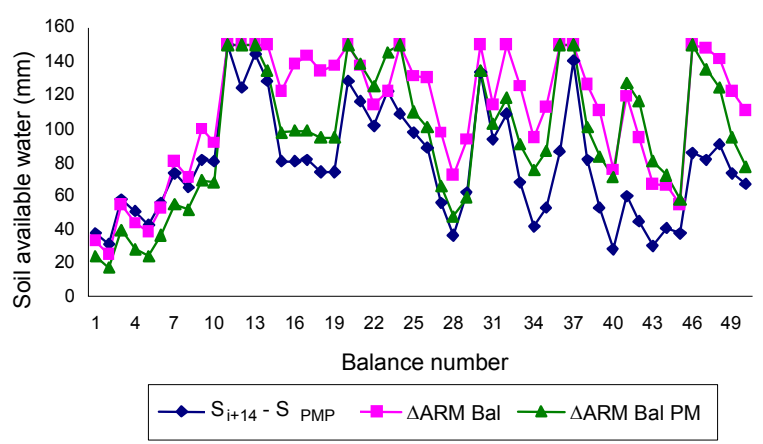

Figure 5 - Amount of soil available water $(\mathrm{mm})$ at the end of each balance, through field measurements $\left(\mathrm{S}_{\mathrm{i}+14}-\right.$ $\left.\mathrm{S}_{\mathrm{PMP}}\right)$ and climatological estimation. $(\triangle \mathrm{ARM})$. 
After this balance, the available water of Bal $\mathrm{T}$ was always overestimated by Bal PM and much more in relation to the direct measurement of Bal C. At this time the coffee plants were more developed, with a greater water demand. For Bal T, with a smaller ETR, the available water reached several times the maximum value of $150 \mathrm{~mm}$, while for Bal C, after balance 11 , the available water never more reached the maximum. For Bal PM, the estimate always got more close to $\mathrm{Bal} \mathrm{C}$, however always with an overestimation of Bal PM in relation to Bal C. It can therefore be said that the estimation of available water or soil water deficits through $\mathrm{Bal} \mathrm{T}$ is problematic and much better through Bal PM.

The comparison of EXC in Bal T and Bal PM with the sum $\mathrm{RO}+\mathrm{QL}$ of $\mathrm{Bal} \mathrm{C}$ is presented in Figure 7 with practically identical linear regressions, also with significative $\mathrm{R}^{2}$, but with individual values varying considerably. In the case of $\mathrm{Bal} \mathrm{C}$, both $\mathrm{RO}$ and $\mathrm{QL}$ are difficult to be measured. In our experiment, with the coffee plants planted along contour-lines $(10 \%$ slope) on a shallow furrow and leaving dead leaf mulch below canopy, runoff was very well controlled and amounted to only $5.5 \mathrm{~mm}$ the first year and $0.8 \mathrm{~mm}$ the second, with an average of $0.3 \%$ of the total rain-

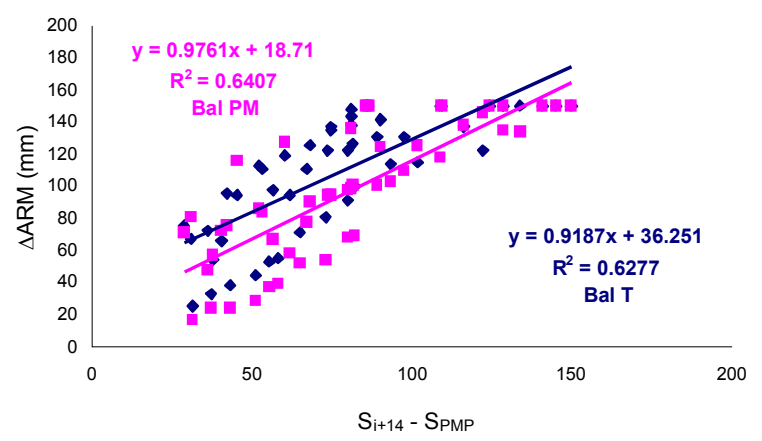

Figure 6 - Linear regressions between amounts of available soil water at the end of each balance through the climatological methods $(\triangle \mathrm{ARM})$ and field measurements.

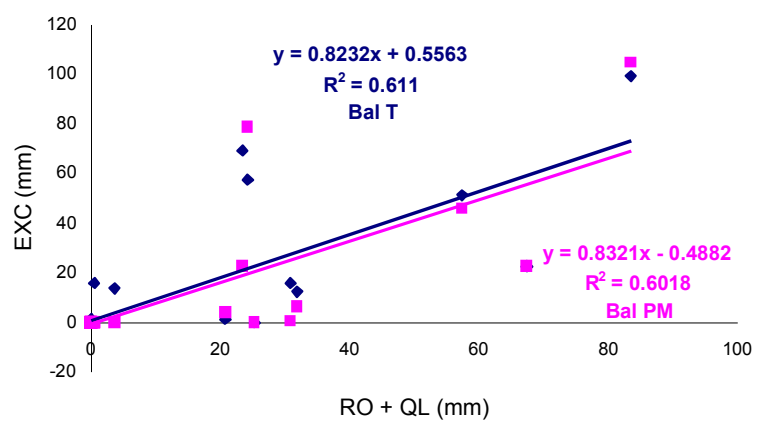

Figure 7- Linear regressions between water excess (EXC) calculated through $\mathrm{Bal} \mathrm{T}$ and $\mathrm{Bal} \mathrm{PM}$, and $(\mathrm{RO}+\mathrm{QL})$ through Bal C. fall, for both years. Therefore, the losses estimated through $\mathrm{Bal} \mathrm{C}$ were practically accounted to QL, a difficult component to be measured due to the spatial variability of the soil $\mathrm{K}(\mathrm{q})$ relation. The estimation of QL using the Darcy-Buckingham approach is discussed elsewhere (Silva et al., 2007). For Bal T and Bal PM, the EXC is simply calculated from the difference missing to close the balance. For the two years, the sum $(\mathrm{RO}+\mathrm{QL})$ and EXC presented differences of 87 and $38 \mathrm{~mm}$, respectively, in favor to (RO+QL) indicating that $\mathrm{Bal} \mathrm{T}$ and $\mathrm{Bal} \mathrm{PM}$ also underestimated these components. This fact becomes more relevant when water balances are performed to estimate runoff, erosion and leaching losses of fertilizers.

\section{CONCLUSION}

Sequential climatologic water balances, based on evapotranspiration estimated by the methods of Thornthwaite and Penman-Monteith, reasonably substituted water balances directly measured in a coffee field. The climatological methods underestimated actual evapotranspiration and soil water storage changes, with a better performance of Penman-Monteith in relation to Thornthwaite. As a consequence, the available water measured in the field was always below estimated values. These climatologic balances also under estimated water excess, therefore indicating less drainage below root zone and smaller possibility of nutrient leaching.

\section{ACKNOWLEDGMENT}

To CNPq for fellowships and to FAPESP for financial support.

\section{REFERENCES}

ALlen, R.G.; PEREIRA, L.S.; RAES, D.; SMITH, M. Crop evapotranspiration guidelines for computing crop water requirements. Rome: FAO, 1998. 300p. (Irrigation and Drainage Paper, 56).

BRUNINI, O.; CAMARGO, M.B.P.; PEDRO JR., M.J.; BLAIN, G.C.; BRUNINI, A.P.C.; CAPUTI, E.; SANTOS, R.L.; BRIGANTE, R.S.; ALMEIDA, E.L. Monitoramento agrometeorológico e o comportamento da cultura do cafeeiro. In: SIMPÓSIO DE PESQUISA DOS CAFÉS DO BRASIL E WORKSHOP INTERNACIONAL DE CAFÉ \& SAÚDE, 3., Porto Seguro, 2003. Anais. Brasília: Embrapa Café, 2003. p.76.

CLIMAPIRACICABA. Dados climáticos: Piracicaba, SP, Brasil. Available in: <http://www.climapiracicaba.hpg.ig.com.br/ piradados.htm>. Access in: Jan. 10, 2006.

EMPRESA BRASILEIRA DE PESQUISA AGROPECUÁRIA. Centro Nacional de Pesquisa de Solo. Sistema brasileiro de classificação de solos. Rio de Janeiro: Embrapa Solos, 1999. 412p.

FARIA, R.T.; CHIBANA, E.Y. Simulação do balanço hídrico do cafeeiro. In: SIMPÓSIO DE PESQUISA DOS CAFÉS DO BRASIL E WORKSHOP INTERNACIONAL DE CAFÉ \& SAÚDE, 3., Porto Seguro, 2003. Anais. Brasília: Embrapa Café, 2003. p.79. 
MEIRELES, E.J.L.; CAMARGO, M.B.P.; FAHL, J.I.; THOMAZIELLO, R.A.; NACIF, A.P.; BARDIN, L. Análise do balanço hídrico seqüencial decendial (2002) para a região cafeeira de Mococa, SP. In: SIMPÓSIO DE PESQUISA DOS CAFÉS DO BRASIL E WORKSHOP INTERNACIONAL DE CAFÉ \& SAÚDE, 3., Porto Seguro, 2003. Anais. Brasília: Embrapa Café, 2003. p.53-54.

PEREIRA, A.R. Balanço hídrico de um solo podzolizado de Lins e Marília cultivado com cafeeiros. Bragantia, v.45, p.239-247, 1986.

PEREIRA, A.R.; ANGELOCCI, L.R.; SENTELHAS, P.C. Agrometeorologia: fundamentos e aplicações práticas. Guaíba: Agropecuária, 2002. 478p.

REICHARDT, K.; TIMM, L.C. Solo, planta e atmosfera: conceitos, processos e aplicações. Barueri: Manole, 2004. 478p.

ROLIM, G.S.; SENTELHAS, P.C. Disciplinas do Departamento de Ciências Exatas: Meteorologia agrícola. Piracicaba: ESALQ/USP, Departamento de Ciências Exatas, 1999. Available in: <http:// www.lce.esalq.usp.br/angelocci/BHaula.xls>. Access in: Jan. 10, 2006.

SENTElHAS, P.C.; ANGELOCCI, L.R. Balanço hídrico: BH Climatológico, Normal e Seqüencial, de Cultura e para Controle da Irrigação, Aula 9. Piracicaba: ESALQ/USP, 2005. (LCE 306 Meteorología agrícola). Available in: <http://www.lce.esalq.usp.br/ aulas/lce306/aula9.pps>. Access in: February 05, 2006.

SILVA, A.L. Variability of the water balance components: a study case in a coffee crop (Coffea arabica L.) in Brazil. Piracicaba: USP/ ESALQ, 2005. 72p. (Ph.D. - Thesis).
SILVA A.L.; ROVERATTI, R.; REICHARDT, K.; BACCHI, O.O.S.; TIMM, L.C.; BRUNO, I.P.; OLIVEIRA, J.C.M.; DOURADO-NETO, D. Variability of water balance components in a coffee crop grown in Brazil. Scientia Agricola, v.63, p.105-114, 2006.

SILVA, A.L.; REICHARDT, K.; ROVERATTI, R.; BACCHI, O.O.S.; TIMM, L.C.; OLIVEIRA, J.C.M.; DOURADO-NETO, D. On the use of soil hydraulic conductivity functions in the field. Soil \& Tillage Research, v.93, p.162-170, 2007.

SOUZA, J.L.M.; FRIZZONE, J.A.; GERVÁSIO, E.S. Simulação do balanço hídrico climatológico decendial para a cultura do cafeeiro, na região de Lavras, Minas Gerais. In: SIMPÓSIO BRASILEIRO DE PESQUISA EM CAFEICULTURA IRRIGADA, 5., Araguari, 2002. Anais. Uberlândia : UFU, 2002. p.156-161.

THORNTHWAITE, C.W. An approach toward a rational classification of climate. Geographical Review, v.38, p.55-94, 1948.

THORNTHWAITE, C.W.; MATHER, J.R. The water balance. Centerton: Drexel Institute of Technology, Laboratory of climatology, 1955. 104p. (Publications in Climatology, 8).

VILLA NOVA, N.A. Dados agrometeorológicos do município de Piracicaba. Piracicaba: ESALQ, Departamento de Física e Meteorologia, 1989.

Received December 11, 2006

Accepted April 13, 2007 